\title{
The Effect of Simulation-Supported Inquiry on South African Natural Sciences Learners' Understanding of Atomic and Molecular Structures
}

\author{
Justin Dunn 1 and Umesh Ramnarain * \\ Department of Science and Technology Education, Faculty of Education, University of Johannesburg, \\ Johannesburg 2006, South Africa; dunnjustin044@gmail.com \\ * Correspondence: uramnarain@uj.ac.za
}

Received: 1 August 2020; Accepted: 10 September 2020; Published: 14 October 2020

check for updates

\begin{abstract}
This study investigated the effect of interactive computer simulation-supported inquiry on South African grade 8 learners' comprehension of atoms and molecular structures. Two sample groups of 34 learners per sample group were used, one acting as a control group who were exposed to a teacher-directed pedagogy while the experimental group used simulations in inquiry-based learning as an intervention to enhance their understanding of atomic and molecular structures. Data were collected by means of conceptual tests, a questionnaire survey, and individual interviews. A statistical analysis of quantitative data gleaned from the post-test showed that the learners in the experimental group performed better than the control group learners. This reflects that the interactive simulations using in an inquiry activity impacted more favorably on the conceptual understanding of learners compared to a teacher-directed approach. The results of the questionnaire survey indicated that learners in the experimental class had a positive experience of using the simulations. They recognized that the simulations enhanced their visualization of abstract concepts, and they reflected on their efficacy in manipulating the simulation.
\end{abstract}

Keywords: simulations; inquiry learning; technology; atomic and molecular structures

\section{Introduction}

Atoms and molecules are fundamental concepts in chemistry, and therefore, are regarded as core topics in the South African Curriculum and Assessment Policy Statement (CAPS) for physical sciences [1]. Atomic structure encapsulates concepts such as models of the atom, atomic mass and diameter, protons, neutrons and electrons, isotopes, energy quantization and electron configuration, while molecular structure covers a chemical bond, molecular shape, electronegativity and bond polarity, bond energy and bond length. Engagement in atomic and molecular structure provides an opportunity to kindle learners' interest in the subject matter [2]. For example, it introduces the idea that all matter consists of small indivisible particles called atoms, which are so small that they cannot be seen by the human eye. Questions exchanged between teacher and learner can invoke the imagination and curiosity of learners to investigate further to formulate an understanding of such phenomena [3].

Due to students' inability to perceive the atom, this contributes to the complex and abstract nature of chemistry, thus making the study of the subject difficult for students [4-6]. A study conducted by Cokelez [7] involving sixth grade and seventh-grade learners showed that they have difficulty developing a mental model about the concept of the atom, with many likening the atom to a sand particle. Similarly, Harrison and Treagust [8] (p. 509) revealed that younger science students have difficulty separating models from reality, with students concluding that "atoms can reproduce and grow and that atomic nuclei divide". This difficulty is persistent with even university students still lacking 
the basic knowledge of what atomic structures and the atomic theory is essentially made up of [9]. Furthermore, a study by Kiray [10] demonstrated that pre-service science teachers had difficulty grasping the atom, electron cloud, and orbital concepts. According to Derman, Koçak, and Eilks [11], there is no unanimous agreement on how these topics should be taught in schools, with different approaches being employed by teachers. However, it is generally acknowledged that the "use of various models and corresponding visual representations in science classes are necessary and beneficial" [11] (p. 3).

The increasing availability of computers and related equipment, such as smartboards and mobile devices, and the corresponding availability of software, such as simulations, especially in science, has resulted in simulations becoming an integral part of science teaching and learning [12]. Teachers use appropriate pedagogical representations, such as computer simulations, which may aid in making these abstract concepts, such as atomic and molecular structure, more accessible to learners [13]. These simulations allow learners to individually construct knowledge on atoms and molecular structures, fostering deep conceptual learning [14]. Simulations allow learners to use their own knowledge and learn through inquiry, thus eradicating the idea that the teacher is the only source of information in a classroom, and recognizing learners' prior knowledge as important for concept formation and understanding of atomic and molecular structures $[15,16]$.

\section{Simulation-Supported Scientific Inquiry}

Inquiry-based science education has been at the cornerstones of school science curriculum reform. The importance that is given to inquiry in the South African curriculum is underlined through Specific Aim 2 of the Curriculum and Assessment Policy Statement where it is stated that "Learners must be able to plan and carry out investigations as well as solve problems that require some practical ability" [1]. Inquiry is often regarded as a fluid construct due to multiple interpretations and perspectives. There is some consensus that scientific inquiry is considered as, " . . the diverse ways in which scientists study the natural world and propose explanations based on evidence derived from their work" [17], and "the process by which scientific knowledge is developed" [18]. Pedaste et al [19] further elaborate that inquiry-based learning is a teaching approach which allows learners to learn through being actively involved in their learning instead of trying to memorize what is being taught to them by their teacher.

Studies have reported the benefits of inquiry-based teaching such as that inquiry-based learning experiences stimulates interest in science [20,21], improves understanding of concepts [22,23], leads to an understanding of the nature of science [24], leads to the development of higher order thinking [25], facilitates collaboration between learners [26] and helps to develop experimental skills [27].

Inquiry-based learning enables learners to be active participants in investigations, making decisions about how and what they learn, identify where they are, engage in active thinking and draw conclusions from the data they have collected [28]. Computer simulations offer an environment for learners that is suited for inquiry, due to the fact that they allow learners to question and explore through experimenting with the simulations $[29,30]$. Computer simulations can be integrated into inquiry learning environments to supported learners in their investigations. Research shows that simulation-supported scientific inquiry can improve learners' conceptual understanding [31]. Studies also reveal that students taught science through simulated inquiry-based learning outperformed those using traditional instruction [32,33]. Furthermore, when simulations are used in relation to the $5 \mathrm{E}$ inquiry instructional model, significant conceptual change can take place to remediate students' misconceptions [34,35].

\section{Integrating Simulations in South African Classrooms}

Simulations can support learning when applied correctly in a classroom. Teaching with simulations is different from using a traditional direct teaching approach as simulations allow learners to learn through discovery, thus fostering a sense of deep learning instead of surface learning amongst learners $[14,36]$. Simulations also enhance the visualization of phenomena, especially when they are coupled with practical activities [37]. Simulations can present rich visual displays of molecules and 
atoms to support learners in their understanding of chemical phenomena and their interactions [38]. This also leads to an increase in a learner's motivation to study the subject matter [39], which may subsequently make learners participate more and become more active learners in class, as increased learner activity is one of the results of using an inquiry-based approach [19].

The integration of ICT in classrooms, though being beneficial, holds many challenges for both learners and teachers. In order for teachers to be effective in teaching with technology, there is a strong need for the training of teachers with these devices [40]. Training will, therefore, allow teachers to broaden their technological pedagogical knowledge and, in essence, enhances their ability to choose the correct type of simulations and recognize its pedagogical value. Despite the aforementioned benefits of simulations, the socio-economic context of a country may impede its implementation. This is certainly the case in a country such as South Africa where only $10 \%$ of the 28,000 schools in South Africa have access to at least one computer [39]. Most schools in rural areas of South African already struggle with issues of overcrowded classrooms, lack of adequate furniture and even a shortage of textbooks. Some of the challenges cited in South Africa include a lack of teaching time, resource inadequacy, large classes, and safety concerns [41]. The affordances of technology, such as simulations, are therefore largely unexplored within the South African context. The use of simulations could provide an alternative to traditional laboratory experimentation that has been constrained due to the aforementioned challenges.

This study investigated how inquiry-based simulations can enhance South African grade 8 natural sciences learners' understanding of atomic and molecular structures. Accordingly, the research was guided by the following two research questions:

1. How does simulation-supported inquiry learning enhance grade 8 learners' understanding of atomic and molecular structures?

2. What are learners' perceptions and experiences of using simulations in making scientific inquiry?

\section{Research Design and Methodology}

The study adopts a mixed-methods approach, which uses a combination of quantitative and qualitative research approaches. Johnson and Onwuegbuzie [42] describe mixed methods research as the third research paradigm after the quantitative and qualitative paradigms. They state that "the goal of mixed methods research is not to replace either of these approaches but rather to draw from the strengths and weaknesses of both in single research studies and across studies" (p. 14). Mixed methods research is described by Johnson and Onwuegbuzie as "the class of research where the researcher mixes or combines quantitative and qualitative research techniques, methods, approaches, concepts, or language in a single study" (p. 17).

In addressing the first research question, a simple randomized control trail (RCT) was followed. According to Hariton and Locascio [43], randomized control trails enable comparison between an experimental group and control group in order to determine the effect of an intervention (such as a simulation) on a learning outcome (such as learner understanding of atomic and molecular structures).

Two similarly academically performing grade 8 natural science classes were randomly chosen as the control class and the experimental class. The learners in each class were also similar in terms of their prior schooling, their first language spoken, and the community they resided in. The learners in the control class were taught atomic and molecular structure by means of a traditional direct teaching approach, whereas the experimental class experienced inquiry-based learning that was facilitated by the use of simulations. Both the control and experimental classes made a structured inquiry on where they investigate using models to build atoms, molecules, and compounds. The investigation was structured in that the teachers provided them with a worksheet that prompted them on what needed to be done. Therefore, while the control class used physical models to build, draw, and investigate the structures, the experimental class used a simulation.

The simulations for this research study were sourced from the Physics Education Technology (PhET) project. PhET was developed by a group of researchers from the University of Colorado at Boulder in the United States of America. The PhET simulations are highly interactive and 
provide animated feedback to the user. These simulations are freely available on the internet and, therefore, accessible to all South Africans. In addition, the PhET simulations can be downloaded onto a computer or laptop and then used without internet connectivity. The PhET simulation experiences by the experimental class were called "Build a molecule" and can accessed by the link https://phet.colorado.edu/en/simulation/build-a-molecule. The following learning goals are provided for this simulation: Describe the differences between an atom and a molecule, construct simple molecules from atoms, recognize that the subscript in the molecular formula indicates the number of that atom in the molecule, recognize that the coefficient indicates the total number of molecules, associate common molecule names with multiple representations. Figure 1 is a screenshot of this simulation.

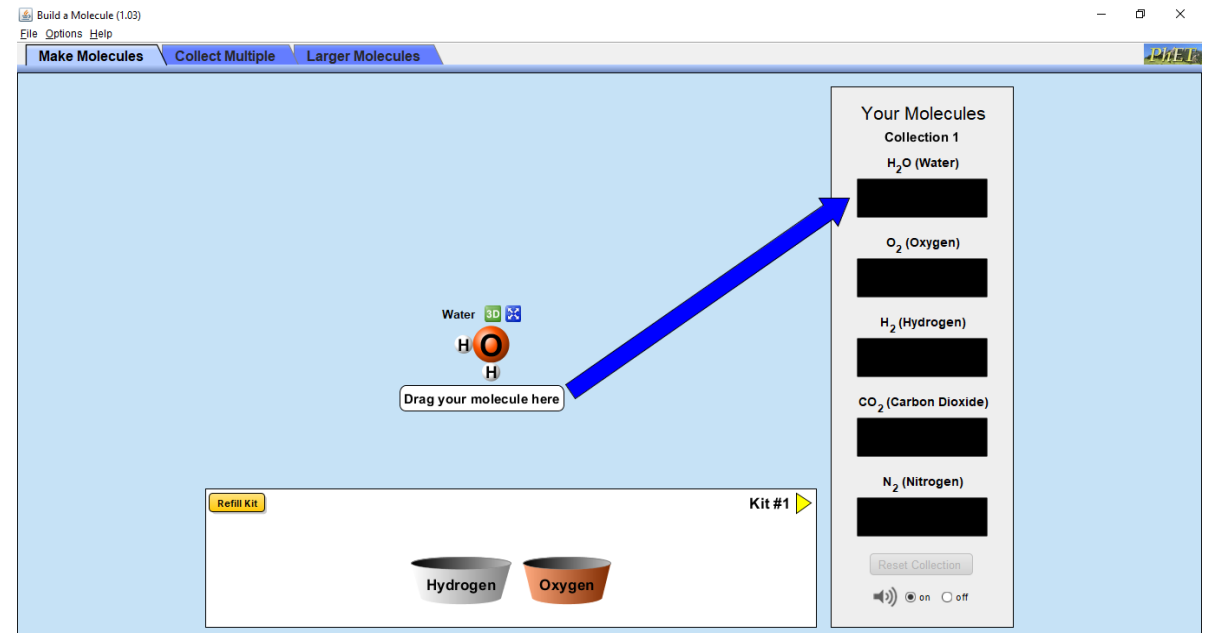

Figure 1. Screenshot of PhET simulation on Build a Molecule. Source: PhET simulation, University of Colorado Boulder.

Quantitative data were collected by means of a pretest on a topic already taught and a posttest that was comprised of items that tested the conceptual understanding of learners on atomic and molecular structures. The items were sourced from tests and examination questions papers that were set by the South African Department of Basic Education. The items were, therefore, valid. The pretest was comprised of six multiple-choice items, and the maximum attainable score was 8 , while the posttest had eight items and these totaled a score of 8 as well. An example of such an item is: A particle that cannot be broken down further is A. compound B. mixture C. element D. atom. See Appendix A for the pretest and posttest. In both tests, students were expected to demonstrate the following capabilities: Understand that atoms are indivisible, identify sub-atomic particles of an atom, identify examples of compound and diatomic molecules, and differentiate between atoms, elements, molecules, and compounds.

The second research question was addressed by means of a questionnaire survey that was administered to the experimental group after the intervention. The questionnaire solicited learners' perceptions and experiences of using simulations in inquiry learning. It was developed by the authors. It was distributed to two researchers in science education for comment on its construct validity. Both researchers commented that the items addressed the intention of the questionnaire. The questionnaire was comprised of five-point Likert scale items, where the options ranged from " $1=$ strongly disagree" to " $5=$ strongly agree". Learners from the experimental group were selected for interviews, whereupon elaboration was sought on the questionnaire responses. These learners were asked to describe their experiences of engaging with the simulation and to identify how this experience was different from a traditional learning experience. The interviews were transcribed for analysis.

The tests yielded quantitative data that were analyzed statistically using SPSS software to yield descriptive statistics, such as the mean, standard deviation, and standard error of the mean. Inferentially, the mean test performances of the groups were compared by $t$-tests. The $t$-test was 
considered appropriate as it is used to assess the "statistical significance of the difference between two sample means for a single dependent variable" [44] (p. 442). The independent-samples $t$-test was conducted by firstly comparing the mean scores of the experimental and control groups in the pretest, and secondly, it was used in comparing the mean scores of these groups in the posttest. Questionnaire data were analyzed descriptively by computing frequencies in responses to the Likert scale and then percentages on these responses.

The qualitative interview data were coded to generate themes [45].

Coding is a research method that a researcher uses when interested in utilizing an entire dataset to identify underlying themes presented through the data [46]. This process entailed firstly reading through the data, in order to get a global overview. Thereafter, excerpts were coded and then placed into categories. The codes were not predetermined but emerged from the data. After coding all the data, the codes sharing the same meaning were grouped together into sub-themes, which were eventually grouped together into themes. Table 1 is an excerpt from the coding book that was developed. For example, the codes "Visual nature of simulation" and "Pictures are better than words" shared a similar meaning and could be placed in the category "Simulations and learner understanding", leading to the theme "Simulations support learner understanding".

Table 1. Excerpt from the interview codebook.

\begin{tabular}{|c|c|c|c|}
\hline Code. & Description of Code & Example from Excerpt & Category \\
\hline $\begin{array}{l}\text { Visual nature of } \\
\text { simulation }\end{array}$ & $\begin{array}{l}\text { Simulation present a visual } \\
\text { image that learners can see }\end{array}$ & $\begin{array}{l}\text { Yes sir, uhm, it makes you } \\
\text { understand a bit better with the } \\
\text { pictures showing you things }\end{array}$ & \multirow{2}{*}{$\begin{array}{l}\text { Simulations and } \\
\text { learner understanding }\end{array}$} \\
\hline $\begin{array}{l}\text { Pictures are better } \\
\text { than words }\end{array}$ & $\begin{array}{l}\text { Simulations aid learning more } \\
\text { than text-based activities }\end{array}$ & $\begin{array}{l}\text { It helps the visual learners in our } \\
\text { class that respond more to } \\
\text { pictures than words }\end{array}$ & \\
\hline $\begin{array}{l}\text { Simulations allows } \\
\text { learner autonomy }\end{array}$ & $\begin{array}{l}\text { Simulations allow learners to } \\
\text { inquire on their own first } \\
\text { rather than having teacher } \\
\text { explain it to them }\end{array}$ & $\begin{array}{l}\text { Yes sir, because when you are } \\
\text { working yourself, sir it is better } \\
\text { to try out then to go and get the } \\
\text { knowledge from the teacher. }\end{array}$ & $\begin{array}{l}\text { Simulations and } \\
\text { learner autonomy }\end{array}$ \\
\hline
\end{tabular}

Ethical clearance to conduct the research was granted by the ethical clearance committee of the university that the researchers are affiliated with (number 2018-041). All participants provided a written consent for data collection. The teachers and learners were informed that they could withdraw from the study at any time. They were also assured that their identity, the identity of the school, and responses would be kept confidential.

\section{Results}

\subsection{Learner Performance}

\subsubsection{Comparison of Control and Experimental Group Pre-Test Performance}

Table 2 presented the results for scores of the control and experimental groups in the pre-test.

Table 2. Pre-test results.

\begin{tabular}{ccccc}
\hline & Mean & N & Std. Deviation & Std. Error Mean \\
\hline Pre-test-control-group & 7.18 & 34 & 1.42 & 0.24 \\
Pre-test-test-group & 6.79 & 34 & 1.07 & 0.18 \\
\hline
\end{tabular}

In comparing the means of both groups, it is apparent there is only a slight difference of 0.38 , thus verifying the equivalence of the two groups in terms of existing performance. 


\subsubsection{Comparison of Control and Experimental Group Post-Test Performance}

In comparing the overall means of the post-test results obtained by both experimental group and control group in it is evident that the experimental group who experienced inquiry-based learning using a simulation have obtained a higher overall mean than the control group (Table 3).

Table 3. Post-test results.

\begin{tabular}{ccccc}
\hline & Mean & N & Std. Deviation & Std. Error Mean \\
\hline Post-test-control-group & 3.65 & 34 & 1.79 & 0.31 \\
Post-test-test-group & 4.29 & 34 & 2.41 & 0.48 \\
\hline
\end{tabular}

The experimental group who experienced the simulated inquiry $(\mathrm{M}=4.29, \mathrm{SD}=2.41)$ performed significantly better than the control class who experienced a traditional direct teacher approach with no simulated inquiry experience $(\mathrm{M}=3.65 ; \mathrm{SD}=1.79)$. A $t$-test revealed that there was a significant difference in the mean scores between the two groups, with the experimental group performing better than the control group $(t(66)=11.9, p<0.05)$. This reflects that the simulation-supported inquiry learning helped to better grasp concepts on atomic and molecular structure compared to the control group who experienced a teacher-directed pedagogical approach.

\subsection{Learners' Perceptions and Experiences of Using Simulations in Inquiry Learning}

Table 4 presents the results from responses to the survey questionnaire on earners' perceptions and experiences of using simulations in inquiry learning.

Table 4. Responses to the questionnaire survey.

\begin{tabular}{|c|c|c|c|c|c|}
\hline \multirow[b]{2}{*}{ Item } & \multicolumn{5}{|c|}{ Responses $(n=34)$} \\
\hline & $\begin{array}{c}\text { Strongly } \\
\text { Disagree (\%) }\end{array}$ & $\begin{array}{l}\text { Disagree } \\
(\%)\end{array}$ & $\begin{array}{l}\text { Neutral } \\
(\%)\end{array}$ & $\begin{array}{l}\text { Agree } \\
(\%)\end{array}$ & $\begin{array}{l}\text { Strongly } \\
\text { Agree (\%) }\end{array}$ \\
\hline $\begin{array}{l}\text { I feel that using computers in a classroom has helped } \\
\text { me better understand the structure of an atom and } \\
\text { what atoms are made up of }\end{array}$ & 5.9 & 0 & 0 & 3.5 & 90.6 \\
\hline $\begin{array}{l}\text { After using computer simulations, I was able to do } \\
\text { the classwork activity without struggling }\end{array}$ & 5.9 & 0 & 2.9 & 8.8 & 82.4 \\
\hline $\begin{array}{l}\text { I prefer to have more lessons using computer } \\
\text { simulations in future }\end{array}$ & 5.9 & 0 & 2.9 & 19.3 & 71.9 \\
\hline $\begin{array}{l}\text { I was able to use the simulations easily after the } \\
\text { teacher explained how the simulations work }\end{array}$ & 0 & 0 & 5.9 & 8.8 & 85.3 \\
\hline $\begin{array}{l}\text { After using simulations, I would want to try using } \\
\text { other computer-assisted learning programs }\end{array}$ & 5.9 & 0 & 8.8 & 17.6 & 67.7 \\
\hline $\begin{array}{l}\text { After these lessons using simulations, I want to } \\
\text { know more about atoms and atomic structures }\end{array}$ & 2.9 & 0 & 8.8 & 11.8 & 76.5 \\
\hline
\end{tabular}

In responding to the statement "I feel that using computers in a classroom has helped me better understand the structure of an atom and what atoms are made up of" an overwhelming 90.6\% of respondents strongly agreed with this statement. This suggests that learners recognized the value of the simulation in supporting their understanding of the atomic structure. The visual feature of the simulation enabled learners to grasp the concept of the atom. This is underlined in the following excerpts from the interviews:

Yes, I do, it helps the visual learners in our class that respond more to pictures than words.

Yes sir, because then we can see how they react with different atoms. 
I would say, sir, the interaction between the two things but not always, sir, because you can't really draw an atom, sir, using computers, sir ... for some people it's difficult, sir.

Despite an overwhelming endorsement for the role of simulations in scientific inquiry, the learners recognized the important role that the teachers would still need to play in guiding them towards understanding science concepts. This is evidenced below from the interview.

Well, not always sir, considering the fact that when the teacher explains it, you understand it a little better

Learners also remarked that the teacher should also closely monitor the activities, especially when mobile devices are used during simulated inquiries. It would appear that some learners now have the necessary discipline to be task-focused. For example, a learner made the following remark during the interview.

\section{No, sir, because instead of doing work they will watch videos on youtube, sir, it will distract them.}

Learners also exhibited a desire to use simulations in future with $91.2 \%$ of them either strongly agreeing or agreeing with the statement "I prefer to have more lessons using simulations in future". A further item related to their difficulty in using the simulation (I find it difficult to use simulations), and here $78.1 \%$ of learners responded "No", suggesting that they did not encounter a challenge in manipulating the simulation. However, some learners in the interview did indicate that they needed support in developing their technological knowledge. This is revealed below.

Well, it depends, sir, well, it depends on what you are using with the computer, sir, the teacher will have to show us beforehand

Clearly, the research elicited strong quantitative and qualitative evidence for the support of simulation-supported scientific inquiry compared to a traditional teacher-directed approach.

\section{Discussion and Conclusions}

The study investigated whether computer simulations in inquiry learning enhanced learners' understanding of atomic and molecular structures. The findings revealed that the experimental group performed better than the control group. It is evident that an inquiry-based approach using a simulation was a more effective approach compared to a traditional direct teaching approach where learners were largely inactive. The findings of this study correlate with the results of other studies (e.g., $[29,30,35,47])$ that found positive impacts of learner inquiry with simulations on learners' understanding of science concepts.

Furthermore, as can be observed from their assessment questionnaire responses, learners consider that the use of ICT, together with the methodology used, has facilitated their learning and has encouraged them to study chemistry and learn more [48]. However, in addition, a relevant aspect of this classroom experience is that, presumably, it favors lifelong learning, since a large percentage of students indicate that "After using simulations, I would want to try using other computer-assisted learning programs". However, this aspect will be explored in depth in further research.

The findings could be of significance to South African science classrooms because as pointed out by Author [49], South Africa's education system, similar to other countries, follows a high-stake assessment system, which often results in teachers "teaching to the test". This, therefore, may result in learners only developing a surface understanding of content taught as opposed to learners experiencing a sense of deep learning. Simulations may also provide a viable alternative to physical laboratories that exist in only a small proportion of South African schools. The findings of this study reveal that incorporating the usage of simulations in a science classroom allows learners to experience a more enhanced understanding of the content learned. The value of simulations, as revealed from the 
results of this study, is that they enable visualization of phenomena that are ordinarily encountered as abstract by learners. By means of visualization, learners acquire an understanding of such phenomena. In particular, the findings of this study reveal that simulations can be exploited in providing viable inquiry-based learning experiences for learners.

International assessments, such as the Trends in International Mathematics and Science Studies (TIMSS), repeated over the years from 1990 to 2003 show that the performance of South African learners in and science, especially black learners from impoverished communities, such as townships, is alarmingly poor compared to other developing countries [50]. More recently, the World Economic Forum report for 2015/16 painted a dismal picture, with South Africa placed at 138 out of 140 countries. The findings of this study invite further investigation in a large-scale study on the impact simulated inquiries may have in addressing the poor performance of learners in science. Future studies should also focus on other topics where concepts are abstract, and that challenge the visualization of learners.

Author Contributions: Conceptualization, J.D. and U.R.; methodology, J.D.; software, U.R.; validation, U.R., Y.Y. and Z.Z.; formal analysis, J.D.; investigation, J.D.; resources, J.D.; data curation, J.D.; writing—original draft preparation, J.D.; writing - review and editing, U.R.; visualization, J.D.; supervision, U.R.; project administration, U.R. All authors have read and agreed to the published version of the manuscript.

Funding: This research received no external funding.

Conflicts of Interest: There are no conflict of interest.

\section{Appendix A}

\section{Appendix A.1. Pretest}

Please indicate your choice by circling the letter of your choice.

1. The smallest particle into which an element can be divided and still be the same substance is called a (1 mark)
a. Neutron
b. Electron
c. Atom
d. Nucleus

2. Atoms consist of which of the following? (3 Marks)
a. Protons
b. Molecules
c. Neutrons
d. Electrons

3. An electron has a ....... charge (1 mark)
a. Positive
b. Negative
c. Neutral

4. A proton has a ...... charge (1 mark)
a. Positive
b. Negative
c. Neutral 
5. A neutron has a ........ charge (1 mark)
a. Positive
b. Negative
c. Neutral

6. $\mathrm{CO}_{2}$ is an example of a: (1 mark)
a. Molecule
b. Compound
c. Element
d. Atom

Total Marks for Pre-Test: 8

Appendix A.2. Posttest

Please indicate your choice by circling the letter of your choice.

1. Which of the following is a definition of a molecule? (1 mark)
a. A molecule is comprised of at least two atoms joined together.
b. A molecule is a mixture of two elements.
c. A molecule is atoms that are not held together by chemical bonds.
d. A molecule is a substance that will not bond with other elements.
e. A molecule is when elements separate into new types of elements

2. Which of the following is a definition of a compound? (1 mark)
a. A compound is a type of molecule consisting of more than one type of element.
b. A compound is a type of molecule consisting of one type of element.
c. A compound is a type of chemical bond where elements are removed.
d. A compound consists of only one atom.
e. A compound is an element that contains no electrons.

3. Which of the following is an example of a compound? (1 mark)
a. A hydrogen molecule comprised of two hydrogen atoms
b. A water molecule comprised of two hydrogen atoms and one oxygen atom.
c. A helium atom comprised of one helium atom
d. A oxygen molecule comprised of two oxygen atoms
e. A jar with a combination of pennies and quarters

4. The negatively charged sub-atomic particles that orbit the nucleus is called ...... (1 mark)
a. Electrons
b. Neutrons
c. Protons

5. A particle that cannot be broken down further is a (1 mark)
a. Compound.
b. Mixture.
c. Atom.
d. Element. 
6. A particle in the nucleus with no electrical charge is known as a (1 mark).
a. atomic number
b. neutron
c. electron
d. isotope

7. A ___ is the building block of matter. (1 mark)
a. nucleus
b. atom
c. proton
d. electron

8. Carbon dioxide is an example of a ... (1 mark)
a. element
b. atom
c. molecule
d. compound

8 Marks

Questionnaire survey

\section{References}

1. Department of Basic Education. Curriculum and Assessment Policy Statement; Government Printing Works: Pretoria, South Africa, 2011.

2. Gafoor, K.A.; Shilna, V. Perceived difficulty of chemistry units in Std IX for Students in Kerala stream calls for further innovations. Online Submiss. 2020. [CrossRef]

3. Chin, C.; Osborne, J. Students' questions: A potential resource for teaching and learning science. Stud. Sci. Educ. 2008, 44, 1-39. [CrossRef]

4. Ramnarain, U.; Joseph, A. Learning difficulties experienced by grade 12 South African students in the chemical representation of phenomena. Chem. Educ. Res. Pract. 2012, 13, 462-470. [CrossRef]

5. Gabel, D.L. Improving teaching and learning through chemistry education research: A look to the future. J. Chem. Educ. 1999, 76, 548-554. [CrossRef]

6. Treagust, D.F.; Chittleborough, G. Chemistry: A matter of understanding representations. In Subject-Specific Instructional Methods and Activities; Brophy, J., Ed.; Elsevier Science: Oxford, UK, 2001; pp. 327-346.

7. Cokelez, A. Junior High School Students' Ideas about the Shape and Size of the Atom. Res. Sci. Educ. 2012, 42, 673-686. [CrossRef]

8. Harrison, A.G.; Treagust, D. Secondary students' mental models of atoms and molecules: Implications for teaching chemistry. Sci. Educ. 1996, 80, 509-534. [CrossRef]

9. Sunyono Wirya, I.W.; Suyanto, E.; Suyadi, G. Identification of Difficulty Problems in Class X Chemistry Learning in Lampung Province. In MIPA Education Journal FKIP; University of Bandar Lampung: Lampung, Indonesia, 2009.

10. Kiray, S.A. The pre-service science teachers' mental models for concept of atoms and learning difficulties. Int. J. Educ. Math. Sci. Technol. 2016, 4, 147-162. [CrossRef]

11. Derman, A.; Koçak, N.; Eilks, I. Insights into components of prospective science teachers' mental models and their preferred visual representations of atoms. Educ. Sci. 2019, 9, 154. [CrossRef]

12. Rutten, N.; van Joolingen, W.R.; van der Veen, J.T. The learning effects of computer simulations in science education. Comput. Educ. 2012, 58, 136-153. [CrossRef]

13. Shulman, L. Those who understand: Knowledge growth in teaching. Educ. Res. 1986, 15, 4-14. [CrossRef]

14. Livingstone, S. Critical reflections on the benefits of ICT in education. Oxf. Rev. Educ. 2012, 38, 9-15. [CrossRef] 
15. Khan, S. New pedagogies on teaching science with computer simulations. J. Sci. Educ. Technol. 2011, 20, 215-232. [CrossRef]

16. Kozma, R.B. Technology and Classroom Practices. J. Res. Technol. Educ. 2003, 36, 1-14. [CrossRef]

17. National Research Council. National Science Education Standards; National Academy Press: Washington, DC, USA, 1996.

18. Lederman, N.G. Syntax of nature of science within inquiry and science instruction. In Scientific Inquiry and Nature of Science; Flick, L.B., Lederman, N.G., Eds.; Kluwer Academic Publishers: Dordrecht, The Netherlands, 2004; pp. 301-317.

19. Pedaste, M.; Mäeots, M.; Siiman, L.; de Jong, T.; van Riesen, S.; Kamp, E.; Tsourlidaki, E. Phases of inquiry-based learning: Definitions and the inquiry cycle. Educ. Res. Rev. 2015, 14, 47-50. [CrossRef]

20. Deboer, G.E. Student-centered teaching in a standards-based world: Finding a sensible balance. Sci. Educ. 2002, 11, 405-417. [CrossRef]

21. Frezell, D. Impact of Inquiry Based Learning on Students' Motivation, Engagement and Attitude in Science. Electronic Theses and Dissertations, University of Windsor, Windsor, ON, Canada, 2018.

22. Dillon, J. A Review of the Research on Practical Work in School Science; King's College: London, UK, 2008.

23. Laksana, D.; Dasna, W.; Degeng, N. The effects of inquiry-based learning and learning styles on primary school students' conceptual understanding in multimedia learning environment. J. Balt. Sci. Educ. 2019, 18, 51-62. [CrossRef]

24. Gaigher, E.; Lederman, N.; Lederman, J. Knowledge about Inquiry: A study in South African high schools. Int. J. Sci. Educ. 2014, 36, 3125-3147. [CrossRef]

25. Conklin, W. Higher- Order Thinking Skills to Develop 21st Century Learners; Shell Education Pub.: Huntington Beach, CA, USA, 2012.

26. Hofstein, A.; Lunetta, V. The laboratory in science education: Foundations for the twenty-first century. Sci. Educ. 2003, 88, 28-53. [CrossRef]

27. Drayton, B.; Falk, J. Tell-Tale Signs of the Inquiry-Oriented Classroom. Natl. Assoc. Second. Sch. Princ. 2001, 85, 24-34. [CrossRef]

28. Ramnarain, U.; Hobden, P. Shifting South African learners towards greater autonomy in scientific investigations. J. Curric. Stud. 2015, 47, 94-121. [CrossRef]

29. Ramnarain, U.; Moosa, S. The Use of Simulations in Correcting Electricity Misconceptions of Grade 10 South African Physical Sciences Learners. Int. J. Innov. Sci. Math. Educ. 2017, 25, 1-20.

30. De Jong, T.; Van Jooligingen, W. Scientific Discovery Learning with Computer Simulations of Conceptual Domains. Sage J. 1998, 2, 179-202. [CrossRef]

31. Chiu, J.L.; DeJaegher, C.J.; Chao, J. The effects of augmented virtual science laboratories on middle school students' understanding of gas properties. Comput. Educ. 2015, 85, 59-73. [CrossRef]

32. Hagemans, M.; van der Meij, H.; de Jong, T. Regulating the inquiry learning process. The effects of a concept map based support tool for simulation-based learning. J. Educ. Psychol. 2013, 105, 1-24. [CrossRef]

33. Vreman-de Olde, C.; de Jong, T.; Gijlers, H. Learning by designing instruction in the context of simulation-based inquiry learning. Educ. Technol. Soc. 2013, 16, 47-58.

34. Bybee, R.W.; Taylor, J.A.; Gardner, A.; Van Scotter, P.; Powell, J.C.; Westbrook A y Landes, N. The BSCS 5E Instructional Model: Origins and Effectiveness; BSCS, Springs: Colorado, CO, USA, 2006.

35. Sahin, N.T.; Pinker, S.; Cash, S.; Schomer, D.; Halgren, E. Sequential Processing of Lexical, Grammatical, and Phonological Information Within Broca's Area. Science 2009, 326, 445-449. [CrossRef]

36. Widiyatmoko, A. The Effectiveness of Simulation in Science Learning on a Conceptual Understanding. J. Int. Dev. Coop. 2018, 24, 35-43.

37. Stieff, M. Improving Learning Outcomes in Secondary Chemistry with Visualization-Supported Inquiry Activities. J. Chem. Educ. 2019, 96, 1300-1307. [CrossRef]

38. Linn, M.C.; Lee, H.-S.; Tinker, R.; Husic, F.; Chiu, J.L. Teaching and Assessing Knowledge Integration in Science. Science 2006, 313, 1049-1050. [CrossRef]

39. Mdlongwa, T. Information and Communication Technology (ICT) as a Means of Enhancing Education in Schools in South Africa: Challenges, Benefits and Recommendations. Ph.D. Thesis, Africa Institute of South Africa, Pretoria, South Africa, 2012. in press.

40. Bansal, D. Benefits of ICT in Education. Bhartiyam Int. J. Educ. Res. 2016, 5, 1-8. 
41. Dudu, W.T.; Vhurumuku, E. Teachers' practices of inquiry when teaching investigations: A case study. J. Sci. Teach. Educ. 2012, 23, 579-600. [CrossRef]

42. Johnson, R.B.; Onwuegbuzie, A.J. Mixed methods research: A research paradigm whose time has come. Educ. Res. 2004, 33, 14-26. [CrossRef]

43. Hariton, E.; Locascio, J.J. Randomised controlled trials-The gold standard for effectiveness research: Study design randomised controlled trials. BJOG Int. J. Obstet. Gynaecol. 2018, 125, 1716. [CrossRef] [PubMed]

44. Schumacher, S.; McMillan, J.H. Research in Education: A Conceptual Introduction; HarperCollins: New York, NY, USA, 1993.

45. Miles, M.B.; Huberman, A.M. Qualitative Data Analysis: An Expanded Sourcebook, 2nd ed.; Sage Publications, Inc.: Thousand Oaks, CA, USA, 1994.

46. Charmaz, K. Grounded theory: Methodology and theory construction, 2nd ed. Int. Encycl. Soc. Behav. Sci. 2015, 10, 402-407.

47. Alfieri, L.; Brooks, P.J.; Aldridge, N.J.; Tenenbaum, H.R. Does discovery-based instruction enhance learning? J. Educ. Psychol. 2011, 103, 1-18. [CrossRef]

48. Pernaa, J.; Aksela, M. Chemistry teachers' and students' perceptions of practical work through different ICT learning environments. Probl. Educ. 21st Century 2009, 16, 80.

49. Ramnarain, U.; Modiba, M. Critical friendship, collaboration and trust as a basis for self-initiated professional development: A case of science teaching. Int. J. Sci. Educ. 2013, 35, 65-85. [CrossRef]

50. Mullis, S.I.V.; Martin, M.O.; Gonzales, E.J.; Chrostowski, S.J. TIMSS 2003 International Mathematics Report: Findings from IEA's Trends in International Mathematics and Science Study at the Fourth and Eighth Grades; TIMSS \& PIRLS International Study Center: Chestnut Hill, MA, USA, 2004.

(C) 2020 by the authors. Licensee MDPI, Basel, Switzerland. This article is an open access article distributed under the terms and conditions of the Creative Commons Attribution (CC BY) license (http://creativecommons.org/licenses/by/4.0/). 